\title{
Pelvic Nodular Histiocytic and Mesothelial Hyperplasia in a Patient with Endometriosis and Uterine Leiomyoma
}

\author{
Yumin Chung · Rehman Abdul · Se Min Jang · Joong Sub Choi · Kiseok Jang \\ Department of Pathology, ${ }^{1}$ Division of Gynecologic Oncology and Gynecologic Minimally Invasive Surgery, \\ Department of Obstetrics and Gynecology, Hanyang University College of Medicine, Seoul, Korea
}

Nodular histiocytic and mesothelial hyperplasia (NHMH) is a rare and benign proliferative lesion composed of histiocytes with scattered mesothelial cells which was first reported in hernia sac by Rosai and Dehner in 1975. 'They described NHMH as a "benign reactive condition simulating a neoplastic process." Since then, several cases have been reported in lung, pleura, inguinal region, urinary bladder, and pelvic cavity. ${ }^{2-9}$ We report a case of incidentally detected $\mathrm{NHMH}$, presenting as a pelvic nodule during laparoscopic surgery for uterine myoma and endometriosis.

\section{CASE REPORT}

The patient was a 38-year-old woman complaining of abdominal discomfort and infertility without previous pregnancy history. A $8.3 \times 5$-cm-sized intramural type myoma was found on gynecologic sonography. There was no medical history of previous abdominal or pelvic surgery. During laparoscopic myomectomy, a left ovarian cyst $(2.6 \times 1.6 \mathrm{~cm}$ in size $)$, a bladder peritoneal mass $(1.6 \times 1 \mathrm{~cm}$ in size), and a small nodule in cul-de-sac cavity were incidentally obtained. The pathologic diagnosis of left ovary cyst and bladder peritoneal mass was endometriosis. Gross examination of the mass in cul-de-sac cavity showed a grayish white and solid nodule, measuring $0.8 \times 0.5 \mathrm{~cm}$ in size. Microscopically, two populations of cells were identified. The

Corresponding Author

Kiseok Jang, MD, PhD

Department of Pathology, Hanyang University College of Medicine, 222-1 Wangsimniro, Seongdong-gu, Seoul 04763, Korea

Tel: +82-2-2290-8248, Fax: +82-2-296-7502, E-mail: medartisan@hanyang.ac.kr

Received: December 10, 2015 Revised: January 6, 2016

Accepted: January 11, 2016 majority of cells showed nodular clusters of round to polygonal cells with moderate amount of pale to pink granular cytoplasm and ovoid or grooved nuclei. The other cell type was low cuboidal cells of stripped arrangement, which were entrapped in nodular clusters (Fig. 1A, B). Immunohistochemically, the round to polygonal cells in nodular lesions showed positivity for the histiocytic marker (CD68) (Fig. 1C), whereas negative for neuroendocrine markers, such as CD56, synaptophysin, and chromogranin. The low cuboidal cells were immunoreactive for pancytokeratin and the mesothelial markers, such as WT-1 and calretinin (Fig. 1D). These histopathologic features are consistent with $\mathrm{NHMH}$.

\section{DISCUSSION}

NHMH is a benign lesion, which is characterized by non-neoplastic proliferation of histiocytes and mesothelial cells. This lesion is very rare and only 20 cases have been reported in the literature (Table 1). Although patients with these tumors range in age from 2 to 80 years, approximately $70 \%$ of the patients are over 40 years old with a mean age of 50.56 . This lesion exhibits a slightly higher predilection for female in a ratio of 1.33 to 1 . NHMHs are mostly incidental findings and occur at the serosal lining. The lung and pleura are the most frequently affected sites and account for $50 \%$ of the NHMH cases. The inguinal region, urinary bladder, and pelvis are less commonly affected sites.

Pathologically, the diagnosis of NHMH is made by identifying nodular proliferation of both histiocytic and mesothelial components supported by immunohistochemistry. The histiocytes are arranged in solid sheets or nests with a mixture of fibrin materials, and they are immunoreactive against CD68. The me- 

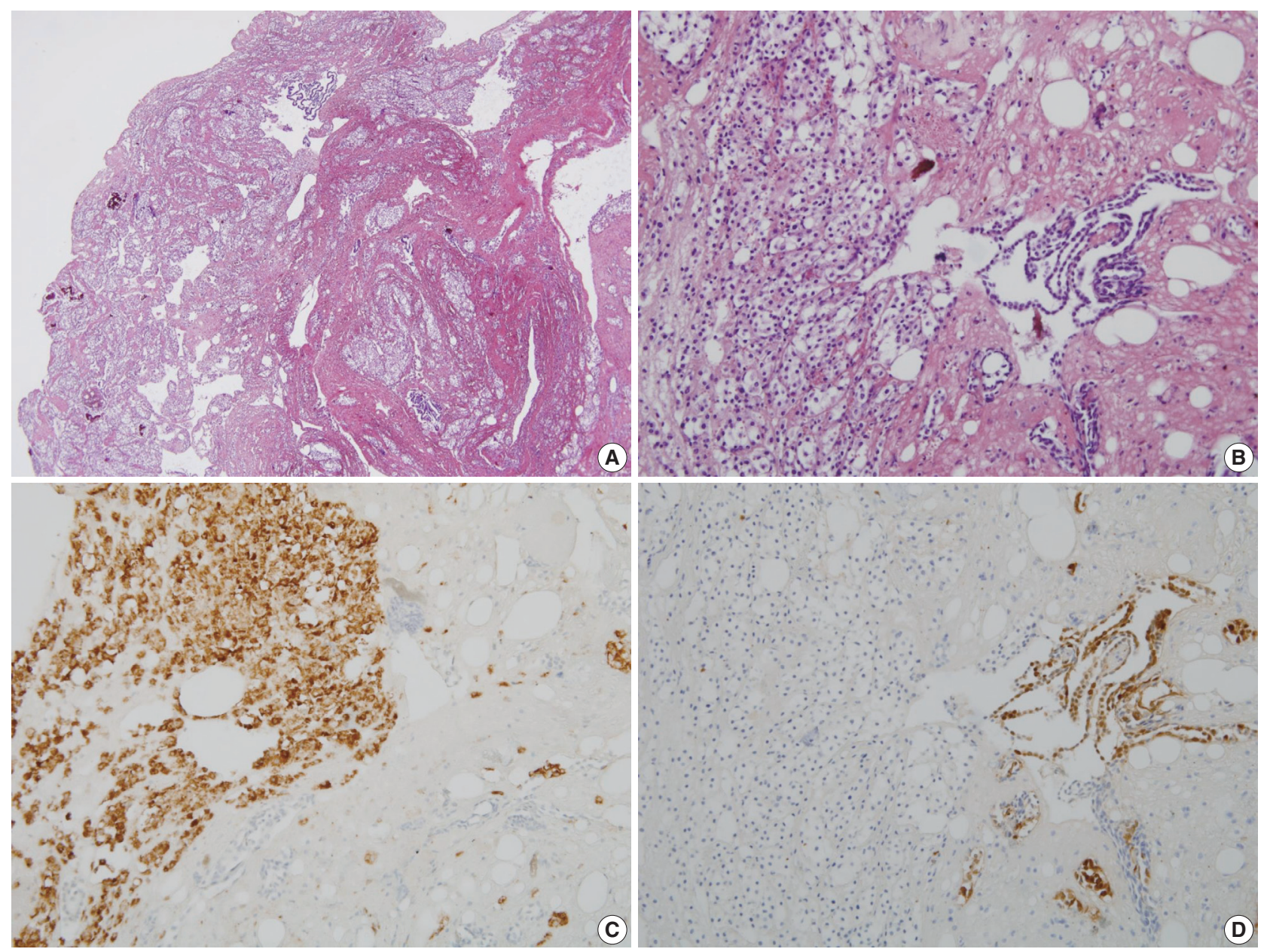

Fig. 1. Pathologic findings. (A) Incidentally obtained pelvic nodule reveals a nodular histiocytic and mesothelial hyperplasia, which is a nodular proliferation of two different cell types, histiocytes and mesothelial cells. (B) High power view shows collection of larger histiocytes, which is admixed with fibrin materials, and strips of smaller mesothelial cells. (C) The histiocytes are immunoreactive for CD68. (D) The mesothelial cells are positive for calretinin.

sothelial component, which is arranged in a glandular- or striplike structure, is positive for mesothelial markers such as calretinin and WT-1. The nuclear atypia is typically absent.

Mesothelial/monocytic incidental cardiac excrescence (MICE), a tumour-like lesion similar to NHMH, is also predominantly composed of histiocytes and scattered mesothelial cells. ${ }^{10}$ It can occur incidentally in pericardium, heart chamber and valve, and it has often been found during cardiac valve replacement surgery. MICE are also considered as a reactive condition. Therefore, NHMH and MICE may belong to the same disease entity.

$\mathrm{NHMH}$ is considered a reactive lesion which results from irritation by inflammation, mechanical trauma, or adjacent tumors. ${ }^{2,6}$ It has been postulated that the nodular aggregation of these reactive cells is mediated by adhesion molecules, such as CD $34 .^{5}$ Although our case did not have mechanical irritation such as previous surgery or procedure, the patient had a large in- tramural leiomyoma and endometriosis as accompanying diseases, supporting the above mentioned pathogenesis.

Although benign-looking cytological findings support that the NHMH represents benign reactive proliferation of histiocytes and mesothelial cells, the lesion can be confused with other mesothelial lesions and neoplasms such as low-grade neuroendocrine tumors, mesothelioma, granulosa cell tumor, Langerhans cell histiocytosis, metastatic carcinoma, seminoma and malignant lymphoma. Therefore, immunohistochemical studies as well as histologic examination with proper clinical history provide clues to obtain an accurate diagnosis. In the present case, the solid pattern of histiocytic proliferation with a delicate capillary network (Fig. 1B) was morphologically similar to the histologic finding of a metastatic renal cell carcinoma and paragangioma, which were excluded by immunohistochemistry.

In conclusion, it is important that pathologists should be aware 
Table 1. Clinical features and pathologicdifferential diagnosis based on previously reported and present cases

\begin{tabular}{|c|c|c|c|c|c|}
\hline No. & $\begin{array}{l}\text { Age }(y r) / \\
\text { Sex }\end{array}$ & Site & Underlying condition & Differential diagnosis & Reference \\
\hline 1 & $57 / \mathrm{M}$ & Lung (LLL) & Old TBC lesions & Neuroendocrine neoplasm & Chan et al. ${ }^{2}$ \\
\hline 2 & $51 / F$ & Lung (RLL) & $\begin{array}{l}\text { Weil-Felix agglutination test (+), } \\
\text { possible rickettsial pneumonia }\end{array}$ & Neuroendocrine neoplasm, ectopic meningioma & Chan et al. ${ }^{2}$ \\
\hline 3 & $23 / F$ & Lleura & Metastatic sarcoma to lung & Metastatic sarcoma & Ordonez et al. ${ }^{3}$ \\
\hline 4 & $78 / F$ & Pleura & Unknown & $\begin{array}{l}\text { Metastatic adenocarcinoma, epithelioid } \\
\text { hemangioendothelioma }\end{array}$ & Ordonez et al. ${ }^{3}$ \\
\hline 5 & $80 / F$ & Pleura & Unknown & $\begin{array}{l}\text { Malignant mesothelioma, metastatic carcinoma, } \\
\text { ectopic meningioma, paraganglioma }\end{array}$ & Choi and Song ${ }^{4}$ \\
\hline 6 & $\begin{array}{l}\text { Elderly/ } \\
\text { M }\end{array}$ & Pleura & Carcinoma in the lung & $\begin{array}{l}\text { Primary or metastatic carcinoma, carcinoid tumor, } \\
\text { mesothelioma, histiocytosis } X\end{array}$ & Chikkamuniyappa et al. ${ }^{6}$ \\
\hline 7 & $53 / F$ & Pleura & Multiple bilateral lung nodules & $\begin{array}{l}\text { Primary or metastatic carcinoma, carcinoid tumor, } \\
\text { mesothelioma, histiocytosis X }\end{array}$ & Chikkamuniyappa et al. ${ }^{6}$ \\
\hline 8 & $79 / \mathrm{M}$ & Lung & $\begin{array}{l}\text { Past history of ischemic } \\
\text { cardiac disease }\end{array}$ & Malignancy & Rossi et al. ${ }^{8}$ \\
\hline 9 & $76 / F$ & Lung (RLL) & $\begin{array}{l}\text { Bilateral pneumonia (history of chronic I } \\
\text { ymphocytic leukemia) }\end{array}$ & $\begin{array}{l}\text { Non-small cell carcinoma, neuroendocrine tumors, } \\
\text { ectopic meningioma }\end{array}$ & Bejarano et al. ${ }^{7}$ \\
\hline 10 & $40 / F$ & Lung (LUL) & Consolidation (lung), scleroderma & $\begin{array}{l}\text { Non-small cell carcinoma, neuroendocrine tumors, } \\
\text { ectopic meningioma }\end{array}$ & Bejarano et al..$^{7}$ \\
\hline 11 & $44 / F$ & Lung (RLL) & $\begin{array}{l}\text { History of pancreatic carcinoma, } \\
\text { history of chemopneumonitis }\end{array}$ & $\begin{array}{l}\text { Non-small cell carcinoma, neuroendocrine tumors, } \\
\text { ectopic meningioma }\end{array}$ & Bejarano et al..$^{7}$ \\
\hline 12 & $78 / F$ & Lung (LUL) & Lung mass & $\begin{array}{l}\text { Non-small cell carcinoma, neuroendocrine tumors, } \\
\text { ectopic meningioma }\end{array}$ & Bejarano et al. ${ }^{7}$ \\
\hline 13 & $46 / M$ & Lung (LLL) & $\begin{array}{l}\text { Bilateral infiltrates (lung) } \\
\text { (s/p heart transplant) }\end{array}$ & $\begin{array}{l}\text { Non-small cell carcinoma, neuroendocrine tumors, } \\
\text { ectopic meningioma }\end{array}$ & Bejarano et al. ${ }^{7}$ \\
\hline 14 & $62 / M$ & Lung (LLL) & $\begin{array}{l}\text { Bilateral infiltrates (lung) } \\
\text { (s/p heart transplant) }\end{array}$ & $\begin{array}{l}\text { Non-small cell carcinoma, neuroendocrine tumors, } \\
\text { ectopic meningioma }\end{array}$ & Bejarano et al. ${ }^{7}$ \\
\hline 15 & $2 / \mathrm{M}$ & Inguinal & Strangulated hernia & - & Chan et al. ${ }^{2}$ \\
\hline 16 & $71 / \mathrm{M}$ & Inguinal & Relapsed inguinal hernia & - & $\begin{array}{l}\text { Suarez-Vilela and } \\
\text { Izquierdo-Garcia }\end{array}$ \\
\hline 17 & $5 / M$ & Inguinal & - & $\begin{array}{l}\text { Neuroendocrine tumors, Langerhans cell } \\
\text { histiocytosis, seminoma, mesothelioma }\end{array}$ & Cai et al..$^{9}$ \\
\hline 18 & $36 / F$ & Pelvis & Infertility & $\begin{array}{l}\text { Well-differentiated adenocarcinoma, } \\
\text { leukemia/lymphoma }\end{array}$ & Chikkamuniyappa et al. ${ }^{6}$ \\
\hline 19 & $37 / F$ & Pelvis & Endometriosis & $\begin{array}{l}\text { Well-differentiated adenocarcinoma, } \\
\text { leukemia/lymphoma }\end{array}$ & Chikkamuniyappa et al. ${ }^{6}$ \\
\hline 20 & $74 / \mathrm{M}$ & Bladder & $\begin{array}{l}\text { Noninvasive papillary transitional } \\
\text { cell carcinoma }\end{array}$ & $\begin{array}{l}\text { Invasive transitional cell carcinoma into the } \\
\text { lamina propria }\end{array}$ & Ordonez et al. ${ }^{3}$ \\
\hline $\begin{array}{l}\text { Present } \\
\text { case }\end{array}$ & $38 / F$ & Pelvis & Uterine leiomyoma endometriosis & Metastatic renal cell carcinoma, paraganglioma & \\
\hline
\end{tabular}

M, male; LLL, left lower lobe; TBC, tuberculosis; RLL, right lower lobe; LUL, left upper lobe.

of this entity and correlate clinically, histologically, and immunohistochemically to make a correct diagnosis.

\section{Conflicts of Interest}

No potential conflict of interest relevant to this article was reported.

\section{REFERENCES}

1. Rosai J, Dehner LP. Nodular mesothelial hyperplasia in hernia sacs: a benign reactive condition simulating a neoplastic process. Cancer 1975; 35: 165-75.
2. Chan JK, Loo KT, Yau BK, Lam SY. Nodular histiocytic/mesothelial hyperplasia: a lesion potentially mistaken for a neoplasm in transbronchial biopsy. Am J Surg Pathol 1997; 21: 658-63.

3. Ordonez NG, Ro JY, Ayala AG. Lesions described as nodular mesothelial hyperplasia are primarily composed of histiocytes. Am J Surg Pathol 1998; 22: 285-92.

4. Choi YL, Song SY. Cytologic clue of so-called nodular histiocytic hyperplasia of the pleura. Diagn Cytopathol 2001; 24: 256-9.

5. Suarez-Vilela D, Izquierdo-Garcia FM. Nodular histiocytic/mesothelial hyperplasia: a process mediated by adhesion molecules? Histopathology 2002; 40: 299-300.

6. Chikkamuniyappa S, Herrick J, Jagirdar JS. Nodular histiocytic/ mesothelial hyperplasia: a potential pitfall. Ann Diagn Pathol 2004; 
8: 115-20.

7. Bejarano PA, Garcia MT, Ganjei-Azar P. Mesothelial cells in transbronchial biopsies: a rare complication with a potential for a diagnostic pitfall. Am J Surg Pathol 2007; 31: 914-8.

8. Rossi G, Cavazza A, Guicciardi N, Marchioni A. Nodular histiocytic/mesothelial hyperplasia on transthoracic biopsy: another source of potential pitfall in a lesion frequently present in spontaneous pneumothorax. Histopathology 2008; 52: 250-2.

9. Cai Z, Xie Q, Wang X, Guo B, Wang X, Wang K. Nodular histiocytic/mesothelial hyperplasia: a clinicopathologic analysis of 7 cases. Zhonghua Bing Li Xue Za Zhi 2014; 43: 256-9.

10. Jiao N, Zhang W, Wang W, et al. Mesothelial/monocytic incidental cardiac excrescence: a case report and review of literature. Int J Clin Exp Pathol 2014; 7: 6219-24. 